\title{
Participating in Parliamentary Politics: Experiences of Indonesian Women 1995-2010
}

\author{
Sharyn Graham Davies and Nurul Ilmi Idrus \\ Auckland University of Technology \\ Hasanuddin University
}

\begin{abstract}
This article concerns itself with women's participation in politics and, more specifically, the representation of women in elected legislatures, in Indonesia between 1995 and 2010. The article gives readers a brief overview of the various ways that Indonesian women participate in politics. Examples are given of women being traditional rulers, having political authority, exercising power, becoming presidents and cabinet ministers, participating in protest movements, and being elected to parliament. The article then moves to focus more specifically on the election of women to the Indonesian parliament. The article analyses positive developments that have occurred in the past decade to facilitate women's entry to parliamentary politics. Although numerous positive developments have indeed taken place, the article argues that women are still hindered in their attempts to get elected to parliament. Drawing on indepth interviews, literature reviews, statistical analysis, and long-term ethnographic research, the authors identify some of the factors limiting women's election, including the restrictive limited model of womanhood advocated in Indonesia, declining cronyism, the ineffectiveness of the thirty per cent quota, the reputation politics has of being dirty, the influence of religion, and the large sums of money candidates need to support their election campaigns.
\end{abstract}

\section{Introduction}

In 1945, Indonesian women were granted the right to vote and stand for election. Indonesian women, however, were already active in the world of politics. As early as 1820 it was noted by a foreign visitor that

1 We would like to thank the editors and the anonymous reviewers for their helpful comments and support. Sharyn Davies would like to thank the Indonesian Embassy in New Zealand, the Asian Studies Institute at Victoria University of Wellington, the Asia New Zealand Foundation and Auckland University of Technology. Thank you also to the International social science journal and Victoria University of Wellington's Asian Studies Institute for allowing the authors to build on previously published material (Davies, 2005; 2008). 
women in the Indonesian province of South Sulawesi were 'consulted by the men on all public affairs, and frequently raised to the throne, and that too when the monarchy is elective'. The visitor, John Crawfurd, continued, 'At public festivals, women appear among the men; and those invested with authority sit in their councils when affairs of state are discussed, possessing, it is often alleged, even more than their due share in the deliberations' (1820: 164). Moreover, during Indonesia's struggle for independence from the Netherlands in the 1930s and 1940s, women were exhorted to be politically active (Bessell, 2004).

For women in the Makassar area of South Sulawesi, authority in the political arena is reflected in the institution of female ada' (ada' bainé), where women act as partners to male members in the traditional governmental council (Röttger-Rössler, 2000). Makassar women may also play the role of mediator between general society and local leaders. Another factor, which might suggest the significance of Makassar women's role in the political arena, is that a husband might obtain a high-standing social position, such as a customary leader, based on the status of his wife (Röttger-Rössler, 2000).

In the spiritual domain Makassar women are also able to exert some political authority. For instance, safeguarding the sacred heirlooms (kalompoang), the possession of which is an important symbol of sociopolitical authority, is deemed to be one of the highest priorities in Makassar society. Those individuals considered best able to protect the heirlooms in some parts of South Sulawesi are women (Röttger-Rössler, 2000). This position of guardian is seen by many as the highest rank within the traditional governmental structure (Röttger-Rössler, 2000). In contrast, men are often excluded from all kalompoang rituals relating to individual belief and familial matters. Such is women's authority within the household and concerning familial affairs in Makassar, South Sulawesi, that Röttger-Rössler (2000) concludes women play significant roles alongside men in many political matters.

In Java, individual power is often contextualised in terms of being selfcontrolled, calm, reserved, and passive (Anderson, 1972). As such, the greater the degree of an individual's power, the less actively such power 
needs to be articulated. For Handayani and Novianto (2004: 182), these former qualities are assigned more readily to femininity than to masculinity. According to Handayani and Novianto (2004), women exercise political power primarily in the private arena and indeed they suggest that power in Java is characterised within the domestic, informal and personal sphere, where women are active contributors. These authors also argue that men's overt and public power is strongly influenced by women's covert, private power. Indeed there is a Javanese saying that apiking suami gumantung istri, apiking anak gumantung $i b u$, which means that husbands and children are the representatives of the wishes of wives and mothers (Handayani and Novianto, 2004: 145, 207-208; cf. Sanday, 1981: 41). Indonesian women also actively participate in politics by undertaking such activities as voting, attending political rallies, fundraising, and lobbying parties and parliament such as during recent debates about the passing of the pornography bill.

Women's political engagement in parts of Indonesia, then, is certainly not a new phenomenon. Considering this relatively long history of political involvement, it may come as a surprise that women's rates of participation in contemporary Indonesian parliamentary politics remains low, despite numerous pro-women policies that have been implemented in the past fifteen years.

In this article we explore the contradictions apparent in women's current parliamentary participation in Indonesia. On the one hand, Indonesian women have made incredible gains in the past fifteen years in terms of their involvement in politics. Perhaps most significant, at least in terms of public recognition of the importance of women in politics, was the passing in 2003 of a quota system recommending that at least thirty per cent of candidates for lower house seats in Indonesia be women. And let us not forget that a woman became president of the world's fourth most populous nation. On the other hand, though, the number of women in lower house seats in Indonesia continues to be low. Here we want to explore some of the reasons why parliamentary participation by women remains low despite some significant advances. 
We have limited discussion in this article to the years 1995 to 2010. One reason for starting in 1995 is that in that year the United Nations' Fourth World Conference on Women was held in Beijing. At this conference all 189 member states agreed to what is now called the Beijing Declaration and Platform for Action (BDPA). The BDPA committed all of the signatories, including Indonesia, to ensure that women had equal access to, and full participation in, power structures and decision making. Davies has written elsewhere specifically about the tenets of the BDPA (Davies, 2005); here we want to look more generally at how the sentiments of the BDPA and other ongoing social developments have sparked interest in Indonesian women's political participation in general and parliamentary participation specifically. The article draws on long-term observation of the Indonesian political system, in-depth interviews, and statistical and literature reviews.

\section{Optimistic Years for Indonesian Women}

The United Nations' Fourth World Conference on Women and the signing of the Beijing Declaration and Platform for Action (BDPA) was a boon for Indonesian women in many respects. In the years that followed the signing of the BDPA many pro-women policies were signed and affirmative activities initiated. Numerous women's groups in the archipelago used tenets of the BDPA as a rallying point for motivating other women to participate in civil society. In many respects the BDPA could not have come at a better time and although it may not be directly cited in many of the developments of the past fifteen years, it was in the background of much pro-women sentiment in Indonesia. Moreover, the BDPA provided impetus in the mid-1990s for many women to protest against the increasingly untenable policies of then President Soeharto.

After three decades as president of the Republic of Indonesia, Soeharto's power began to wane in 1995 . He was desperate to consolidate his rule and tried all sorts of tactics to achieve this. One tactic was to imprison anyone who was critical of him or his government. Another he used to maintain power was to eliminate freedom of the press. The highly 
popular and critical news magazine, Tempo, was banned because it was considered to be undermining the government and was therefore deemed disruptive to Soeharto's rule.

Rather than consolidate Soeharto's power, many of these strong-arm tactics had the reverse effect. People began taking to the streets to protest against unsatisfactory conditions. A particular event that sparked public protest was the 1997 general election where Soeharto's puppet party, Golkar, won 74 per cent of the vote. Civil unrest continued to grow throughout 1997 until Soeharto was forced to resign as president in May 1998.

The environment of open protest was supported in no small part by women. Women from all sectors of society felt empowered to speak out and demand particular rights. A newly emerging middle-class cohort of women was graduating from university and these women were equipped with the skills and nous for protest. Many women were tired of the image of conservatism that had dominated throughout Soeharto's rule and some even set up women's organisations and linked to international networks. Blackburn (2001) notes that rally cries were heard throughout Indonesia and women chanted key words such as 'participation', 'emancipation' and 'empowerment'.

Women's public protests were fuelled by the crashing Indonesian economy in 1997. Daily necessities, such as rice and oil, became comparatively expensive. These price rises caused women to start

2 Even members of Dharma Wanita began protesting. Dharma Wanita is an Indonesian organisation for the wives of civil servants. Indeed, all such wives are obliged to join this organisation. The hierarchy of Dharma Wanita follows that of the civil service. For instance, the wife of a senior ranking civil servant takes a corresponding role within Dharma Wanita. Members of Dharma Wanita are often considered to strategically enjoy their shadow authority and competition amongst members is fierce. For instance, women compete amongst each other to advance the position of their respective husbands because the spouse's status reflects on a woman's own character. In the late 1990s, women in Dharma Wanita began criticising the organisation for being out of touch with issues women faced in the real world. For instance, one senior ranking member, Dr Atiek Wardiman, publicly chastised the organisation for being too preoccupied with social events and ignoring more important matters, such as women's right to education. However, the view of many people in Indonesia is that members of Dharma Wanita continue to put their individual needs before the needs of women in general. 
protesting because they felt they were unable to feed their families adequately. During Soeharto's rule, the state disseminated very clear models of manhood and womanhood. These models defined women as wives and mothers. Any failure of a woman to feed her family meant that she was an inadequate wife and mother. A consequence of this strong model of womanhood was that when rice prices rose and women found it increasingly difficult to feed their families, they felt justified in protesting. The Indonesian model of womanhood was created to ensure that women did not disrupt national stability, yet ironically this model became the justification for protest (McCormick, 2003).

Popular culture in Indonesia from the late 1990s onwards began to show new images of women. Women were portrayed as assertive, independent and powerful. Examples of these new images are found in films such as Eliana, Eliana and Ada Apa Dengan Cinta [What's Up with Love] and in Ayu Utami's novel, Saman (1998). Even women's magazines, such as Jurnal Perempuan [Women's Journal], showed politically active women (cf. Armando, 2000; Hatley, 2007; Suryakusuma, 2000). Not only were women playing central roles in fiction, but in real life women were also assuming key public posts.

In 2001, a woman became president of Indonesia. Megawati Soekarnoputri's victory cannot be separated from the legacy of her father (former President Soekarno) though and, moreover, Megawati was consistently painted as being merely a puppet of her husband, Taufik Kiemas. Yet despite the controversy regarding a woman becoming president, and the fact that she showed little concern for women's issues, Megawati's candidature gave women throughout the nation a particular role model that they could aspire to. ${ }^{3}$

Another boon for women came when the current president of Indonesia, Susilo Bambang Yudhoyono, came to power in 2004 and appointed four women to key cabinet posts. We might have expected a woman to assume the position of State Minister for the Empowerment of Women, as Dr Meutia Hatta Swasono did. We might also have expected that a

3 See Machali (2001) for a discussion on women, Islam and Javanese culture in relation to Megawati Soekarnoputri's presidency. 
woman might become the Minister of Health, as Dr Siti Fadillah Supari did. What took many people by surprise, though, was that women were appointed to two posts not traditionally considered appropriate for women. Dr Sri Mulyani Indrawati became the Minister of National Development Planning and Dr Marie Elka Pangestu became the Trade Minister.

During the 2009 national election campaign the role of women was again debated. Indeed, the vice-chairman of the Democratic Party, Achmad Mubarok, seemed to suggest that women should not be appointed to strategic positions in the government because they were not capable and because women should focus on their family responsibilities. Mubarok accepted that women could assume the portfolios of Social Affairs and Women's Empowerment, but he denied their ability to lead any other ministry (Idrus, 2009). Despite such opposition, after Yudhoyono was reelected president in 2009, he again appointed women to key ministerial posts. Dr Indrawati took the finance portfolio and Dr Pangestu the position of Minister of Trade. Dr Endang Sedyaningsih was appointed Minister of Health, Dr Armida Alisjahbana became Minister of National Development Planning, and Linda Agum Gumelar became the Minister of Women's Empowerment (Idrus, 2009). Sadly for Indonesia though, Dr Indrawati recently resigned as Finance Minister and on the first of June 2010 took up a position as managing director of the World Bank.

In addition to these developments there was, during the period 1995-2010, a number of positive policies aimed at women. In 1995, Soeharto's government designed a National Action Plan. This plan outlined concrete steps to improve the role and status of women in Indonesia and had five main goals and thirty activities. These goals and activities have been outlined elsewhere (Davies, 2005) so here we shall just summarise them. First, the plan was to ensure that all organisations, private and public, would give more opportunities to women. The plan established a mentoring system, whereby women who had already achieved positions of respect in institutions, such as universities and government departments, would mentor women in the lower ranks. The plan also was to give women access to education, leadership, and 
management programs. Finally, the plan envisaged developing good coordination between all sorts of groups, such as between government, universities and the mass media. It was hoped that such developments and collaboration would, inter alia, foster women's engagement in parliamentary politics.

Not only were these initiatives written into policy but they were funded. One form of funding came through Presidential Instruction 5 of 1995. Funding made available by the government enabled the construction of new offices concerned with women's affairs. For instance, the Office of the Advancement of Women was inaugurated and numerous women's studies centres were opened at universities throughout the country. These initiatives aimed in part at helping women get elected to parliament by providing them with such resources as political knowledge. ${ }^{4}$

A particularly important development for women trying to get elected to parliament was the implementation of the thirty per cent quota. In 2003, an election bill (Article 65 (1) UU 12 of 2003) was passed by the Indonesian government recommending that a minimum of thirty per cent of candidates for Assembly seats be women. This bill publicly affirmed the value of women in parliament. The next year there was a national election and women's groups held their breath to see if more women would be elected to parliament. These groups were to be disappointed, though, as this article will show.

4 A further political initiative was also developed to help women achieve equality with men not just in politics but in wider society. On 19 December 2000, Presidential Instruction 9 was issued, which moved gender mainstreaming into national development programs and policies for gender equity in development. This initiative became one of the Millennium Development Goals (MDG) 2015. In 2002, under Megawati's presidency, the State Minister for the Empowerment of Women issued Manual for Implementation Guidelines on Gender Mainstreaming in National Development. This manual was to facilitate gender equity. One way in which this was to be achieved was through integrating women's and men's experiences and by systematically evaluating governmental policies. The development of the manual was followed by a Minister of Internal Affairs Decision (Kepmendagri) 132 of 2003 on General Implementation Guidelines on Gender Mainstreaming at the Regional Level, which was mandated a five per cent allocation of national and regional budgets (Article 7:1). This Kepmendagri has been controversial, though, because the funding allocation is directed solely to the Women's Empowerment Unit. A revised version of Kepmendagri (15 of 2008), again focusing on gender mainstreaming, is far from being institutionalised, though, even ten years after the development of Presidential Instruction 9 of 2000 . 
In another promising move towards parliamentary equity, the election bill of 2003 was substituted in 2008 by UU 10 of 2008. This later regulation not only recommends that a minimum of thirty per cent of candidates for Assembly seats be women, but requests that each party provide a document from its National Party Board proving this to be so (Article 15, d). Parties who do not fulfil this requirement are asked by the General Election Commission to revise their candidate lists; however there are no formal sanctions for non-compliance.

The efforts of women on the ground to increase their participation in politics, particularly parliamentary politics, can also not be ignored. Indeed, with the assistance of foreign donor agents, numerous training programs have been implemented, which have enabled women to build their capacity to engage in formal political structures. For instance, during November and December 2008, the Asia Foundation worked in collaboration with the University of Indonesia's Center for Political Studies, the Indonesian Women's Genuine Partnership (MISPI) in Aceh, the University of Airlangga's Human Rights Center, and with the Makassar Institute of Public Policy Studies (LSKP) to provide candidates from Jakarta, Aceh, East Java and South Sulawesi with a series of electoral training programs. These training programs focused on such matters as the Indonesian electoral system and campaign strategies.

\section{The Challenges for Women and Political Participation}

As can be seen, there is a great deal to feel positive about in terms of women's achievements in the political field in Indonesia over the past fifteen years: a woman became president; numerous pro-women policies and initiatives were implemented; a thirty per cent quota system was ratified; and popular media began to show women as assertive and independent individuals. Unfortunately, these developments have failed to result in substantial increases in the number of women in parliament. The number of women in lower houses of parliament or in unicameral legislatures in Indonesia dropped between 1997 and 2004 from 11.4 per 
cent to 11.3 per cent. By 2009, however, this figure had risen to 18.0 per cent (see Table 1).

In the context of South Sulawesi, only seven of fifty seats (14 per cent) were won by women in the 2009 election for the metropolitan House of Representatives (DPRD Makassar). These seven included two seats for the Hanura Party and one each for the following parties: Golkar, PPP, PAN, PRN and PBN. At the provincial elections (DPRD South Sulawesi), only eleven out of seventy-five seats (14.67 per cent) were won by women. So why has the number of women in lower or single house seats throughout Indonesia remained relatively low over the past fifteen years?

Table1

Lower or Single House Seats Occupied by Women as a Percentage of Total (Indonesia: 1997, 1999, 2004, 2009)

$\begin{array}{llcc}1997 & 1999 & 2004 & 2009 \\ 11.4 \% & 8.0 \% & 11.3 \% & 18.0 \%\end{array}$

Source: Women in National Parliaments, available at:

http://www.ipu.org/wmn-e/arc/classif251297.htm (for 1997)

http://www.ipu.org/wmn-e/arc/classif151200.htm (for 1999)

http://www.ipu.org/wmn-e/arc/classif310105.htm (for 2004)

http://www.ipu.org/wmn-e/classif.htm (for 2009)

There are numerous reasons why Indonesian women find it difficult to get elected to parliament. Below, we investigate six of these reasons, although we acknowledge that further work is needed to identify the full range of obstacles hindering women's engagement in Indonesian parliamentary politics. The reasons identified below are not necessarily addressed in order of significance because these factors come together in different and dynamic ways to hinder individual women's participation in parliamentary politics. Indeed, obstacles to political participation differ depending on the status and position of the woman. For instance, a wealthy woman might be able to access the financial resources needed 
to promote herself politically, but she could find that the political connections she once relied on to get elected have now become a liability, with the public potentially seeing her as someone who engages in KKN (korupsi, kolusi, nepotisme). Moreover, the various political parties differ in their attitudes and policies towards supporting the inclusion of women, a topic that requires further investigation.

A primary contributing factor in limiting the number of women in parliament is the strictness of national Indonesian ideals of womanhood; models of womanhood have been described in some detail elsewhere (Davies, 2006). In reference to political participation, before Indonesian women can legitimately enter politics they should marry heterosexually and bear children. All the women appointed to ministerial posts in the cabinet of Susilo Bambang Yudhoyono have met these requirements. Women must also assure the citizenry that their domestic duties are taken care of and that they are able to work in the public sector in addition to their roles within the home. Indeed, a woman's commitment to her family is continually questioned. If familial problems do occur, the wife is frequently held solely responsible. Moreover, if a wife is more successful in her career than her husband, she is generally seen as a threat to the husband's position as head of the household. We were recently told by one well-educated and politically active woman, Ibu Dian, that people often assume that women who enter politics will neglect their husbands and their children. But this is definitely not the case, Ibu Dian affirmed. She continued by saying that in fact women are perfectly capable of fulfilling all of their domestic duties and still holding down political jobs. Although Ibu Dian is supportive of women engaging in parliamentary politics, she does not question the belief that women must concomitantly continue with their domestic duties. In order to successfully engage in the public arena, it seems women must be superwomen.

The model of womanhood that Indonesian women should emulate is certainly not unique. Another research project explores ways in which Helen Clark, former prime minister of New Zealand, was subjected to inquiries about her femininity and her home life during election 
campaigns. The New Zealand public even demanded assurances that her heterosexual marriage was not just a charade (Devere and Davies, 2006). In Indonesia, however, the model of womanhood is even stricter and it is unlikely that an unmarried woman or a woman without children would be successful in Indonesian politics.

There are certainly advantages for women in employing the Indonesian model of womanhood; Indonesian women have strategically used stereotypical models to their political advantage. For instance, women have asserted that issues such as reproductive health, family welfare, and children's education can only be understood by women. As such, Indonesian women have demanded that more women be included in parliament (cf. Reerink, 2004; Thompson, 2003). However, although arguments based on women's roles as wives and mothers are incredibly empowering, they have their limits. The image of women as domestically focused only stereotypes them to the point that their political careers become something that they can only do once their family is cared for. Moreover, women politicians often find it hard to be taken seriously because the public frequently assumes that politics is just something they do on the side, after they have attended to the welfare of their family.

A second reason why women find it hard to get into parliamentary politics in Indonesia, and why the number of women in lower house parliamentary seats in unicameral legislatures has not grown significantly in the past fifteen years, is possibly because of the declining level of nepotism that has resulted from the democratisation of the political system. The nepotism that arguably helped Megawati (Soekarno's daughter; Soekarno was Indonesia's first president), Siti Hardiyanti Rukmana (Soeharto's daughter), and Meutia Hatta Swasono (Muhammad Hatta's daughter; Hatta was Indonesia's first vice-president) get into power is no longer reliable. Moreover, the Indonesian public has become increasingly sceptical of perceived political nepotism.

Third, although more women may be standing for elections now, in accordance with the thirty per cent quota, women are being nominated for electorates where they are unlikely to win. As Mulia and Anik 
(2005: 120) argue, the quota system has been implemented only halfheartedly — no sanctions are applied to political parties that do not fill the stipulated quota. Indeed, the motivation of legislators to pass the bill has often been seen in the media as coming not from a concern to ensure gender equality, but rather from pressure from a few key women activists who could have negatively influenced the careers of the legislators. Moreover, where women do get elected they mostly are given peripheral positions with little power or input to decision making.

Around election times, many of the media scrutinise parties who fail to meet the minimum thirty per cent quota for women legislative candidates. In response to such accusations of failing to meet the quota, political parties posit numerous reasons why they do not meet the quota. Some parties assert that there is a lack of good women candidates with political competence or that women are reluctant to be nominated. It has also been suggested by a number of media outlets that parties are expecting the quota requirements to be phased out. But because of media exposure, parties often quickly recruit women solely for the sake of appearing to meet the quota. As such, an increase has taken place in the number of women nominated to contest elections but this does not translate into the large numbers of women entering parliament. It seems that the introduction of a quota system, without strong political commitment to reforming the larger electoral system, will not bring about significant positive political change that will allow women to enter parliament on their merits.

Parties often claim that there is a lack of suitable women candidates, but this is often not the case. Indeed, in some instances a political party may support a less suitable man candidate over a more qualified woman, as the following case reveals. One of Golkar's most established politicians was a woman, Andi Sugiarti Mangun Karim, who had been with this political party for over twenty years and was serving as the Head of the House of Representatives (DPRD) in Bantaeng, South Sulawesi. During an election in 2008, she stood against a male colleague named Arfandi. Arfandi was also from Golkar and was at the time a member of 
the House of Representatives at the provincial level (DPRD Provinsi). Arfandi and Karim both stood for nomination for the position of Regent of Bantaeng (Pilkada Bantaeng). According to one survey conducted by Golkar, Karim received 19 per cent of the nomination vote compared with Arfandi's 15 per cent. Yet Golkar did not support Karim, they supported Arfandi. As a result, Karim sought electoral support from other political parties to become vice-regent. She nevertheless lost the election. Golkar then fired Karim ostensibly because she had sought non-Golkar assistance. Yet many men Golkar politicians had also used other political parties for support and incurred no sanctions. For instance, during an election for the governor of South Sulawesi in 2008, a Golkar candidate, Syahrul Yasin Limpo, made use of other parties to increase his profile. When Limpo won the election, Golkar acknowledged him as an outstanding Golkar politician. Karim has now joined another party (the Republican Party) and is a member of the House of Representatives at the provincial level in South Sulawesi, but it would seem that the way in which men and women political candidates are treated varies greatly (Idrus, 2008a; 2008b).

A fourth reason why women find it difficult to enter parliamentary politics relates to the reputation that politics has in Indonesia, and indeed elsewhere, of being rough (kasar) and dirty (kotor) and therefore not a profession considered appropriate for women. Popular culture does present images of women as assertive and independent but these images continue to be exceptions and women receive mixed messages from the media about what they should aspire to (Aripurnami, 2000).

Afifth factor making it hard for Indonesian women to enter parliamentary politics relates to religion. Although Islam has not emerged as the barrier many people expected, there has nonetheless been debate about whether it is acceptable for Muslim women to be involved in politics (Platzdasch, 2000).

Finally, a sixth reason hindering women's election in representational politics relates to the large sums of money required to become a parliamentary candidate. 
The aim of this article is at giving a brief introduction to the issues facing women in their attempts to engage in electoral politics and, as such, further research and analysis needs to be undertaken of the factors limiting women's participation in parliamentary politics. ${ }^{5}$

It is hard to predict what the future holds for women's political and, more specifically, parliamentary participation in Indonesia. There are moves within Indonesia to grant particular provinces regional autonomy. The effect such moves will have on women in politics is unclear. Yuli Ismartono (personal communication, 2008) has suggested that increasing regional autonomy will create a place for women in parliamentary politics. Conversely, Professor Dewi Fortuna Anwar (personal communication, 2008) fears that this system will localise power and make it more difficult for women to rise through the political ranks. Sharon Bessell (2004), in an excellent article covering the issues concerning women in Indonesia's parliaments, tends to reinforce Professor Anwar's view. If political parties are wise, they will realise the benefits of placing women in winnable seats and we will, it is to be hoped, soon see more women in parliament. Being a wife and mother are important roles, but women should also be supported to take on other positions. Women constitute more than half of all eligible voters; if they can find the confidence to support other women, Indonesia will have a bright future. Indeed, the slowly increasing number of women representatives in elected legislative institutions, nationally and regionally, is an encouraging sign.

5 Indeed, there are numerous other factors contributing to women's low rates of participation in Indonesian parliamentary politics, and politics more generally. For instance, one further reason relates to the fact that many of the pro-women policies implemented are limited to introducing a gender mainstreaming strategy, popularly known in Indonesia as sosialisasi, which does not significantly help women participate in parliamentary politics. Gender mainstreaming is generally understood as a program for women's empowerment rather than as an effective strategy for gender equity. Lack of political commitment by government elites and the low enthusiasm of government officials to work towards the implementation of gender mainstreaming are among many of the obstacles that make gender affirmative strategies difficult to integrate with various programs and policies. An Indonesian popular journal, Jurnal perempuan, has published special editions on gender mainstreaming (2006a) and on gender budgeting (2006b), which not only detail activities related to implementing this strategy, but also express the frustration of those who get involved in such activities and see little result (see also Idrus, 2006; Idrus et al, 2006). 


\section{References}

Anderson, B. (1972). 'The idea of power in Javanese culture'. In (ed.) C Holt, with assistance by B Anderson and J Siegel. Culture and politics in Indonesia.Ithaca: Cornell University Press. pp. 1-69.

Aripurnami, S. (2000). 'Whiny, finicky, bitchy and revealing: the image of women in Indonesian films'. In (eds) M Oey-Gardiner and C Bianpoen, Indonesian women: the journey continues. Canberra: Research School of Pacific and Asian Studies. pp. 50-65.

Armando, A. (2000). 'Perempuan di media: rupawan, aduhai dan manja' [Women in the media: good-looking, beautiful, and spoilt]. Jurnal perempuan, 13 (MarchMay): 29-32.

Bessell, S. (2004). 'Women in parliament in Indonesia: denied a share of power'. (Discussion paper, available at http://apseg.anu.edu.au/degrees/pogo/ discussion_papers/PDP04-7.pdf). Canberra: Australian National University. Retrieved from http://apseg.anu.edu.au/degrees/pogo/discussion_papers/ PDP04-7.pdfdoi:http://apseg.anu.edu.au/degrees/pogo/discussion_papers/ PDP04-7.pdf

Blackburn, S. (2001). 'Women and the nation'. Inside Indonesia, 66 (April-June): 6-8. Available at www.insideindonesia.org/edit66/susan61.htm.

Crawfurd, J. (1820). History of the Indian archipelago: containing an account of the manners, arts, languages, religions, institutions, and commerce of its inhabitants. Vol. 3. Edinburgh: Archibal Constable and Co.

Davies, SG. (2005). 'Women and politics in Indonesia in the decade post-Beijing'. International Social Science Journal, 57(184): 231-242. (2006). 'Gender and status in Bugis society'. In (ed.) S Epstein. Understanding Indonesia. Wellington: Victoria University of Wellington Press. pp. 93-106.

------. (2008). 'The contradictions of Indonesian women's participation in politics'. In (ed.) S Epstein. Understanding Indonesia: foreign policy, Islam and democracy. Wellington: Asian Studies Institute. pp. 23-32.

-------. (2010). Gender diversity in Indonesia: sexuality, Islam, and queer selves. London: Routledge Curzon.

Devere, H and SG Davies. (2006). The Don and Helen New Zealand election 2005: a media a-gender. Pacific journalism review, 12(1): 65-85.

Handayani, CS and A Novianto. (2004). Kuasa wanita Jawa [Javanese women's power]. Yogyakarta: LKIS.

Hatley, B. (2007). 'Arts and popular culture'. In (ed.) S Joseph. Encyclopaedia of women and Islamic cultures Vol. 5. Leiden: Brill Publishers. pp. 98-103.

Idrus, NI. (2006). Kajian cepat analisis gender dan kemiskinan Kabupaten Gowa [Rapid assessment of gender and poverty in Gowa Regency]. United Nations Development Programme, Kementrian Pemberdayaan Perempuan, and Pemerintah Kabupaten Gowa.

(2008a). Affirmative action. Fajar, 26 August 2008. 
(2008b). 'Diskriminasi partai politik' [Political party discrimination]. Fajar, 1 July 2008.

Idrus, NI. (2009). 'Seputar jilid II' [Around for the second time]. Fajar, 27 October 2009. Accessed 20 February 2009 at: http://www.fajar.co.id/index.php?option $=$ news\&id $=72173$.

Idrus, NI, AT Tristiana and NA Basira. (2006). Kajian cepat analisis gender dan kemiskinan Kabupaten Gowa [Rapid assessment of gender and poverty analysis in Gowa Regency]. United Nations Development Programme, Kementrian Pemberdayaan Perempuan, and Pemerintah Provinsi Sulawesi Selatan.

Jurnal perempuan. (2006a). 'Pengarusutamaan gender' [Gender mainstreaming]. Jurnal perempuan 50.

-------. (2006b). 'Sudahkan anggaran kita sensitive gender?' [Is our budget gender sensitive?]. Jurnal perempuan 46.

Machali, R. (2001). 'Women and the concept of power in Indonesia'. In (ed.) S Blackburn. Love, sex, and power: women in Southeast Asia. Clayton: Monash Asia Institute. pp. 1-15.

McCormick, I. (2003). 'Women as political actors in Indonesia's New Order'. Unpublished manuscript, University of Melbourne.

Mulia, SM and F Anik. (2005). Perempuan dan politik [Women and politics]. Jakarta: Gramedia Pustaka Utama.

Platzdasch, B. (2000). 'Islamic reaction to a female president'. In (eds) C Manning and $\mathrm{P}$ van Dierman. Indonesia in transition: social aspects of Reformasi and crisis. Singapore: ISEAS. pp. 336-350.

Reerink, A. (2004). 'Labour movements, women's politics'. Paper presented at the Asian Studies Association of Australia Conference, 29 June-3 July, Australian National University, Canberra.

Röttger-Rössler, B. (2000). 'Shared responsibility: some aspects of gender and authority in Makassar society'. In (eds) R Tol, K van Dijk and G. Acciaioli. Authority and enterprise among the peoples of South Sulawesi. Leiden: KITLV Press. pp. 143-160.

Sanday, P. (1981). Female power and male dominance: on the origins of sexual inequality. Cambridge: Cambridge University Press.

Suryakusuma, J. (2000). 'Perempuan, pornografi dan budaya pop' [Women, pornography and pop culture]. Jurnal perempuan 13 (March-May): 33-35.

Thompson, MR. (2003). 'Female leadership of democratic transitions in Asia'. Pacific Affairs 75(4): 535-556.

Utami, A. (1998). Saman. Jakarta: Kepustakaan Populer Gramedia. 